\title{
ANALYSIS OF CHANGES IN PRICES OF LAND IN THE VICINITY OF NATIONAL ROADS
}

\author{
Wioleta Radziszewska, M. Sc. \\ Faculty of Geodesy and Cartography \\ Warsaw University of Technology \\ e-mail:w.radziszewska@gik.pw.edu.pl \\ Joanna Jaroszewicz, PhD \\ Faculty of Geodesy and Cartography \\ Warsaw University of Technology \\ e-mail: j.jaroszewicz@gik.pw.edu.pl
}

\begin{abstract}
Over the last several years, Poland has experienced dynamic development of linear infrastructure, mainly regarding national roads. The changes are reflected in the condition of the market of land located in the vicinity of newly constructed roads. The location of a property in the vicinity of an express road junction offers more convenient access to the labour market or sales market. On the other hand, possible negative effects include increased noise and pollution, as well as spatial continuum disturbance.

The objective of the study is the analysis of the effect of national roads on the development and dynamics of changes in prices of land in their vicinity. The estimation of the dynamics of such changes permits the determination of the stage of implementation of investments involving the highest variations of property prices. The analysis was conducted based on the following criteria: class of national roads (motorway or main express road) and the size of the urban centre located on route. The study involved the application of the Geographic Information Systems technology ArcGIS ESRI, data from the register of property prices and values, and cadastre information included on websites iGeoMap and Geoportal.
\end{abstract}

Key words: national roads, development of land property prices, Geographic Information Systems (GIS).

JEL Classification: R39.

Citation: Jaroszewicz J., Radziszewska W., (2013), "Analysis of Changes in Prices of Land in the Vicinity of National Roads", Real Estate Management and Valuation, vol. 21, no. 1, pp. 77-87.

DOI:10.2478/remav-2013-0010.

\section{Introduction}

Numerous road investments are currently conducted in Poland. Their location is related to irreversible changes in space. The changes are particularly distinctive in rural areas adjacent to roads under construction or those undergoing modifications.

The most significant opportunities and threats to the development of rural areas are particularly related to the construction of national roads which, pursuant to the regulation of the Minister of Transport and Marine Economy of 2 March 1999 on technical conditions required for public roads and their location, correspond to the functional-technical classes of motorways, express roads, main express roads, and main roads. The implementation of such large supraregional undertakings always results in changes in the existing system of land use and management, the acreage structure of 
agricultural farms, and natural environment.

The rural property market responds to the processes of spatial transformations related to road investments relatively fast. It is the dynamic in suburban areas. The invested former agricultural areas are usually transformed into family housing estates. Their road accessibility and distance from an urban centre are the main factors determining the value of land property. The farther they are located, the less attractive and valuable they are likely to be for potential investors, except for the case of them having special purpose (WOLNY, ŹRÓBEK 2008; RADZISZEWSKA, JAROSZEWICZ, SZAFRANEK 2012).

In view of the above considerations, the objective of the article is the analysis of the effect of national roads on the development and dynamics of changes in prices of land in their vicinity. The estimation of the dynamics of changes in the prices will permit the determination of the stage of implementation of investments involving the highest variations of property prices. The study was conducted with the application of the Geographic Information Systems technology ArcGIS ESRI, data from the register of property prices and values, and cadastre information included on websites iGeoMap and Geoportal.

\section{Analysis of market prices of undeveloped land in the vicinity of national roads}

The analysis concerns market prices of undeveloped land from the period 2003-2012, located in the Białystok poviat in the vicinity on national road No. 8 along section Białystok-Sochonie-Katrynka, and from the period 2004-2012, located in the Mińsk poviat in the vicinity of the ring road of Mińsk Mazowiecki (with motorway parameters) along national road No. 2 section Choszczówka-Węzeł Ryczołek. The selection of the study area involved the determination of transactions regarding undeveloped parcels with investment potential, distinguished by: regular shape, size up to $4000 \mathrm{~m}^{2}$, current agricultural management with low bonitation classes of soils in the vicinity of developed areas, or purpose for construction resulting from the local spatial management plans.

\subsection{Mińsk Mazowiecki ring road}

The ring road with a length of approximately $20.85 \mathrm{~km}$ runs on the northern side of Mińsk Mazowiecki. It is incorporated into the existing route of road No. 2, in the vicinity of the Choszczówka Rudzka village to the west, and in the vicinity of the Ryczolek village to the east. It runs through four communes: Dębe Wielkie, Mińsk Mazowiecki, Jakubów, and Kałuszyn. Three road junctions exist along the ring road ("Arynów", "Lotnisko", and "Ryczołek"). The route runs in the corridor of the planned motorway A2 with motorway parameters (ENVIRONMENTAL IMPACT REPORT 2006).

The course of motorway A2 along the section of the Mińsk Mazowiecki ring road has been known for a number of years. The older and currently binding planistic documentation stipulate a provision of land against the construction of the motorway. Its final location approved in 2008 does not differ considerably from the course of the land provision determined earlier. In July 2005, a tender procedure for the execution of the technical design of the road was conducted. In early 2008, a decision on the determination of the location of the road was issued. Finally, in October, the governor of the Mazowsze Voivodship issued a decision approving the project, and permitting the construction with the order of immediate enforceability. In August 2009, construction works commenced. They lasted for three years, and the motorway section was commissioned on 29 August 2012 (www.a2obwodnica-minska.pl).

The analysis of the local property market along the Mińsk Mazowiecki ring road was conducted based on data from the register of property prices and values run for the following communes: Dębe Wielkie, Mińsk Mazowiecki, Jakubów, and Kałuszyn. Information on transactions in the years 20042012 was used.

\subsubsection{Analysis of the distribution of transaction prices of properties in particular periods of the implementation of the investment}

The first stage involved the determination of time intervals related to the most important stages of implementation of the investment. They are presented in Table 1.

The transactions analysed were divided into three periods (Fig. 1):

1) 108 property sale transactions concluded in period $A B$,

2) 181 property sale transactions concluded in period $C D$,

3) 12 property sale transactions concluded in period $\mathrm{E}$.

Due to the small sample of transactions concluded in period E, they were not subject to analysis. 
Table 1

Stages of the implementation of the investment

\begin{tabular}{cccc}
\hline designation & $\begin{array}{c}\text { date of } \\
\text { commencement }\end{array}$ & $\begin{array}{c}\text { date of } \\
\text { completion }\end{array}$ & description \\
\hline A & $2004-01-01$ & $2005-07-17$ & $\begin{array}{c}\text { until resolving the tender for the } \\
\text { execution of the road technical design }\end{array}$ \\
\hline B & $2005-07-18$ & $2008-03-14$ & $\begin{array}{c}\text { until the approval of the final location } \\
\text { decision }\end{array}$ \\
\hline C & $2008-03-15$ & $2009-08-24$ & until the commencement of the \\
construction
\end{tabular}

Source: own elaboration

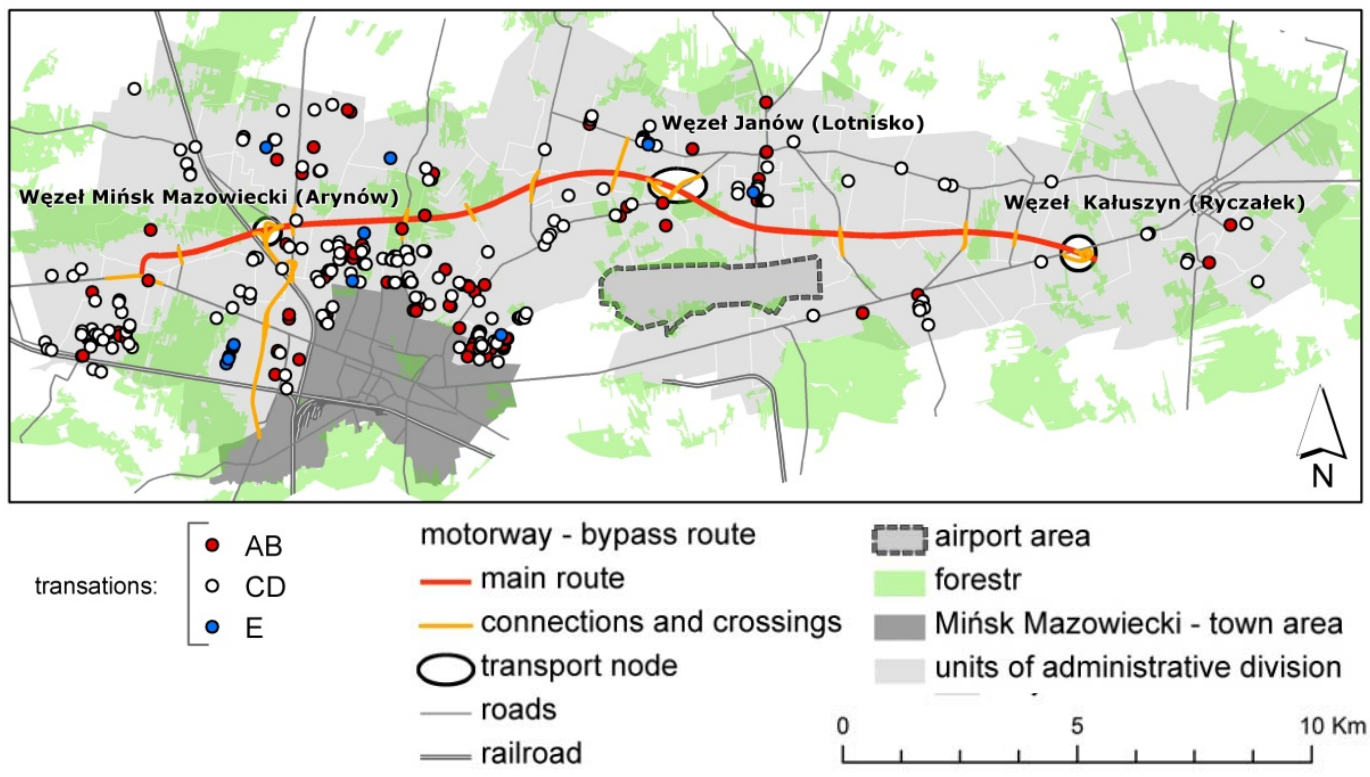

Fig. 1. Distribution of transactions analysed in the years 2004-2012 in three periods (AB, CD, and E) of the execution of motorway A2 along the Mińsk Mazowiecki ring road. Source: own elaboration.

The estimation of similarity of prices of neighbouring transactions involved the application of spatial statistics tools. ArcGIS ESRI software has an implemented tool permitting the determination, based on the Anselin's method from the mid 1990's, of local values of the Moran's value coefficient I (Anselin Local Morans I). Moran's I identifies patterns (clustered, random, dispersed) and measures their strength. It compares the difference in values between each pair of neighbours to the difference in values between all features in the study area. If the average difference between neighbouring features is lower than that between all features, the values are clustered. The resulting information specifies statistically significant concentrations of similar values (clusters), and occurring outliers. Clusters of values can correspond to high or low values (MITCHELL2005). The analysis results are presented in Figure 2.

The following designations were used: $\mathrm{HH}$ (similar high values), LL (similar low values), HL (transaction with a price much higher than the neighbouring transactions), LH (transaction with a price much lower than the neighbouring transactions). The terms similar/varying are construed as statistically significant lower/higher variation of values in the vicinity (locally) in relation to the average value of difference determined for all the pairs of points. Statistical significance is determined based on the " $\mathrm{z}$ " measure: $z=\frac{I_{\text {observed }}-I_{\text {expected }}}{S D_{I}}$, where $S D_{I}$ is standard deviation of Moran's I calculated under randomisation assumption. The calculation formulas can be found for example in CATMOG (Concepts and Techniques in Modem Geography), the publication by M.F. GOODCHILD (1986), or in ArcGIS 10.1 Help. The conceptualisation of spatial relationships was determined as the 
function of inverse square distance.
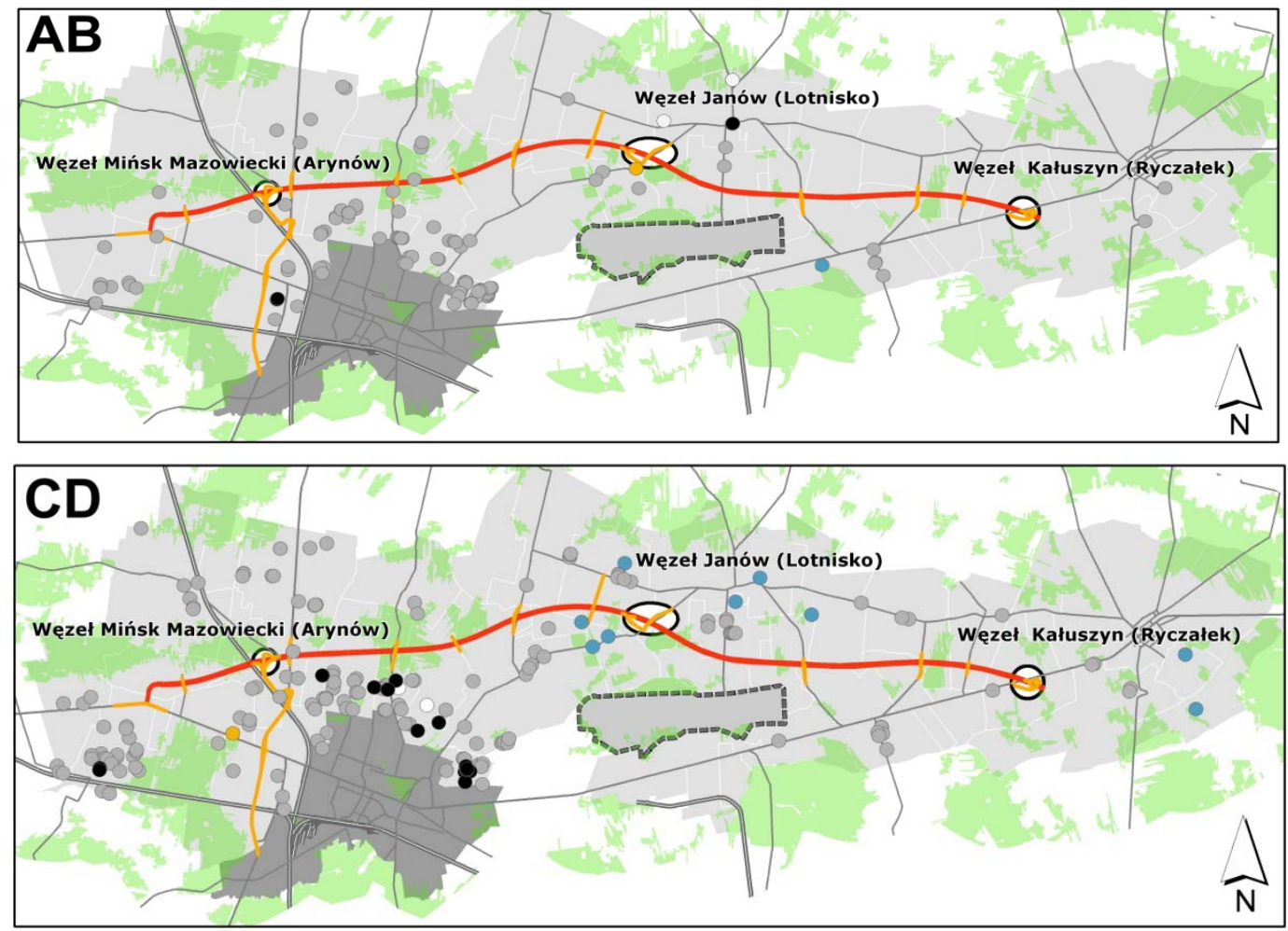

- Not Significant
- $\mathrm{HH}$
- $\mathrm{HL}$
LH
- $\mathrm{LL}$

motorway - bypass route

- main route

connections and crossings

$\bigcirc$ transport node

_ roads

_ railroad

airport area

forestr

Mińsk Mazowiecki - town area units of administrative division

$5 \quad 10 \mathrm{Km}$

Fig. 2. Results of the analysis of clusters of similar and varying values of properties in two periods: $A B$ and CD. Source: own elaboration.

Figure 2 shows no occurrence of distinctive clusters of high or low transaction prices in the period before the commencement of the construction of the ring road (AB). One cluster of high values, composed of only two parcels, occurs in the centre of the Jakubów village. It includes two small parcels purposed for construction. Another cluster is a pair of regularly shaped parcels in the western suburb of Mińsk Mazowiecki, with good communication with the city and a road to Warsaw. One transaction was distinguished by the property sale price (PLN 92.38/ $\mathrm{m}^{2}$ ) much higher than the surrounding ones. It concerned a parcel located directly at the exit from motorway A2 ("Lotnisko" junction) in the direction of the planned civil airport. Interestingly, the transaction was concluded before the tender procedure for the execution of the road technical design. Prices considerably lower than the neighbouring transactions distinguish two large parcels located in the peripheral area of the Jakubów village, purposed for homestead housing. The transactions were concluded at the end of 2006 and at the beginning of 2007.

In the period after the commencement of the construction of motorway A2 along the Mińsk Mazowiecki ring road (CD), a very large high value cluster composed of a number of transactions occurs in the north-eastern suburbs of Mińsk Mazowiecki in villages: Królewiec, Wólka Mińska, and Karolina. They are mainly transactions from the period 2011-2012, with prices exceeding PLN 150 per square meter. The parcels are purposed for residential housing, and are distinguished by good road access to both Mińsk Mazowiecki and the motorway junction. Some of them are located at a distance lower than 600 metres from the motorway. Another small cluster of high values is composed of transactions of parcels located in Chrośla. Much more sale transactions involving property purposed for construction in comparison to transactions from period $\mathrm{AB}$ were recorded in Chrośla. 
A cluster of low values, composed of many transactions, occurs in the vicinity of Jakubów. They are property sale transactions from 2010 and 2011, located in Stara Niedziałka and Niedziałka Druga, at a distance of 300-500 metres from the motorway, and approximately $2 \mathrm{~km}$ from the "Lotnisko" junction. The property is purposed for homestead housing with possible residential housing. Another group of low values are property sale transactions also located in the vicinity of the Jakubów village, but concluded in the period 2008-2009. Small clusters of low values are also composed of property sale transactions located behind Kałuszyn in Patok and Moczydła.

The appearance of blue points, standing for a low value cluster (LL), does not have to entail a decrease in transaction prices in the area. Their detection with the application of a statistical algorithm can result from an increase in the differentiation of prices in a given area, and the appearance of considerably higher transaction values in the vicinity of Mińsk Mazowiecki.

The analysis also revealed "varying" transactions, i.e. a parcel located directly at national road No. 2 in the Choszczówka Stojecka village, sold in September 2009 (for a price higher than the neighbouring transactions), and two parcels purposed for homestead housing with possible residential housing, purchased in 2008 (Wólka Mińska) and 2011 (Karolina) in villages located between the boundaries of Mińsk Mazowiecki and its ring road (for a price lower than the neighbouring transactions).

During eight years of the execution of the Mińsk Mazowieckiring road, considerable changes occurred in the development of prices of land in the vicinity of the investment. The highest dynamics were observed in the period 2011-2012, when the construction of the ring road was close to completion. High values of properties in the two periods analysed were located at the Arynów junction and in the vicinity of Mińsk Mazowiecki. Close vicinity to Mińsk Mazowiecki, convenient access to Warsaw, and developed road infrastructure determine the attractiveness of the property. Transactions related to properties from the period 2008-2009 in the typically agricultural commune Jakubów reach substantially lower values. The situation might also be a response to the then valid tendency in regional and national markets for restricting the credit policy which resulted in a slowdown on the property market.

\subsubsection{Classification of properties in terms of transaction date and unit price}

The analysis involved the application of the classification procedure for detecting natural clusters of data analysed. The procedure was implemented in the form of a tool of grouping analysis in ArcInfo ESRI software. It is based on the K-means algorithm. Geographical objects (transaction locations) ascribed to a given group are similar to each other as much as possible. The groups are maximally different from each other. The similarity between objects is determined based on attributes ascribed to each of them. For the transactions analysed, the attributes were transaction date and price per square meter. The most suitable number of groups for qualification can be determined with the application of procedures of estimation of grouping effectiveness of e.g. pseudo F-statistic following CalinskiHarabasz (CALINSKI, HARABASZ 1974, ArcGIS 10.1. Help). A detailed report is developed permitting the assessment of the classification conducted. For the area of Mińsk Mazowiecki, 6 groups of transactions were distinguished. The coefficient $\mathrm{R}^{2}=0.8657$ for the date criterion, and $\mathrm{R}^{2}=0.8514$ for the price per square meter criterion. The coefficient $\mathrm{R}^{2}$ is calculated as $R^{2}=\frac{S S T-S S E}{S S T}$, where SST reflects between-group differences - cluster separation - value calculated as the sum of square deviations for the entire set, and SSE reflects within-group similarity - cluster cohesion - value calculated as the sum of square deviations in particular groups. The lower the differentiation of values of attributes in the groups, the lower the value obtained for SSE, and the better grouping (PANG-NING, STEINBACH, KUMAR 2006).

Properties were classified by transaction date and unit price, and consequently divided into six groups (Fig. 3):

a) Three groups after the commencement of the construction of the ring road:

- group 1, marked with red colour, represents transactions distinguished by high prices;

- group 2, marked with orange colour, represents transactions distinguished by average prices;

- group 3, marked with yellow colour, represents transactions distinguished by low prices.

b) Three groups before the commencement of the construction of the ring road:

- group 4, marked with green colour, represents transactions distinguished by average prices; 
- group 5, marked with light blue colour, represents transactions distinguished by low prices;

- group 6, marked with dark blue colour, represents the oldest transactions distinguished by low prices.

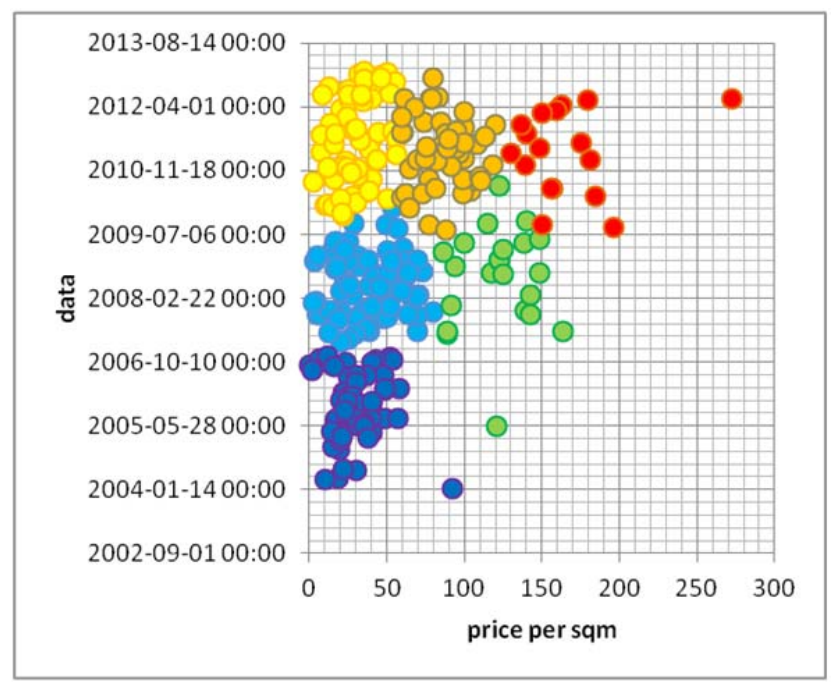

Fig. 3. Graph of values of criteria of division into groups by the attributes of transaction date and price per $1 \mathrm{~m}^{2}$. Source: own elaboration.

The spatial distribution of transactions by groups is presented in Figure 4.

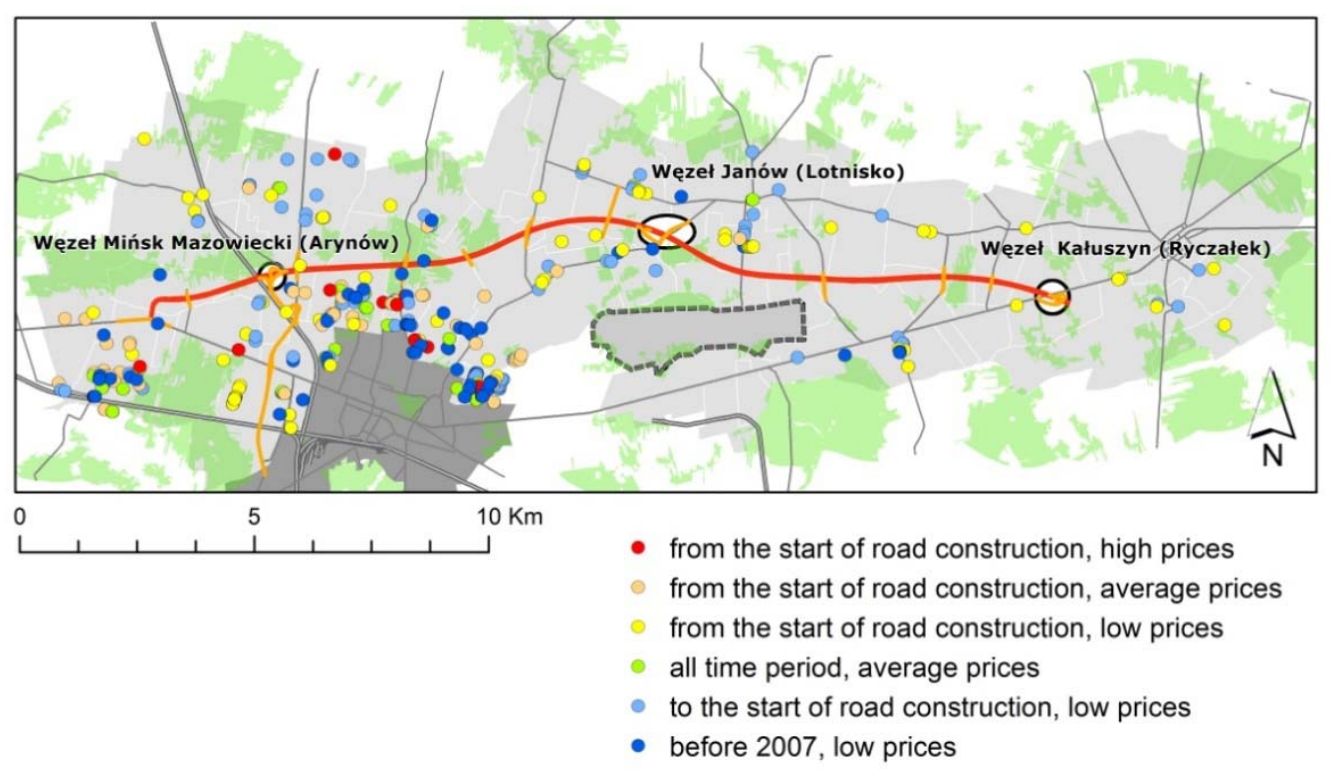

Fig. 4. Distribution of transactions belonging to particular groups. Source: own elaboration.

In the typically agricultural communes Jakubów and Kałuszyn, a relatively low number of transactions are concluded. The obtained transaction prices in those areas are definitely lower. Average prices were only obtained in the vicinity of Mińsk Mazowiecki, and from the moment of commencement of the road construction, a group of high prices appeared in the area (red colour). The reason for the appearance of this transaction group can be the fact of the commencement of the construction of the motorway, providing the city with a chance for the avoidance of the onerousness of transit transport in the future, and in a longer perspective, with convenient motorway access to the capital city.

\subsection{National road No. 8 along section Białystok-Sochonie-Katrynka}

The Podlasie Voivodship is one of the weakest communication links in Poland. The only interregional connection between the capital city of Poland and cities of eastern Poland is national 
road No. 8. The road is a communication route constituting the main and almost exclusive access to the recreational areas of the Augustów and Suwałki Lakelands, and farther to the eastern border of the country. Therefore, works on the development of the road have been conducted for the last several years for the purpose of making travelling by both trucks and cars more efficient. In 2008, construction works in the scope of extension of national road No. 8 commenced along section Białystok-SochonieKatrynka with a length of $6.4 \mathrm{~km}$, located within the administrative boundaries of commune Wasilków. Three road junctions exist along the ring road ("Sielachowskie", "Jurowce", "Sochonie"). Particular stages of the implementation of the investment are presented in Table 2.

Table 2

Stages of implementation of the investment

\begin{tabular}{cccc}
\hline designation & $\begin{array}{c}\text { date of } \\
\text { commencement }\end{array}$ & $\begin{array}{c}\text { date of } \\
\text { completion }\end{array}$ & description \\
\hline A & - & $2001-05$ & $\begin{array}{c}\text { until resolving the tender procedure for } \\
\text { the execution of the road technical } \\
\text { design }\end{array}$ \\
\hline B & $2001-05$ & $2007-03-19$ & until the approval of the final location \\
decision
\end{tabular}

Source: own elaboration

2.2.1. Analysis of the distribution of transaction prices of properties in particular periods of implementation of the investment

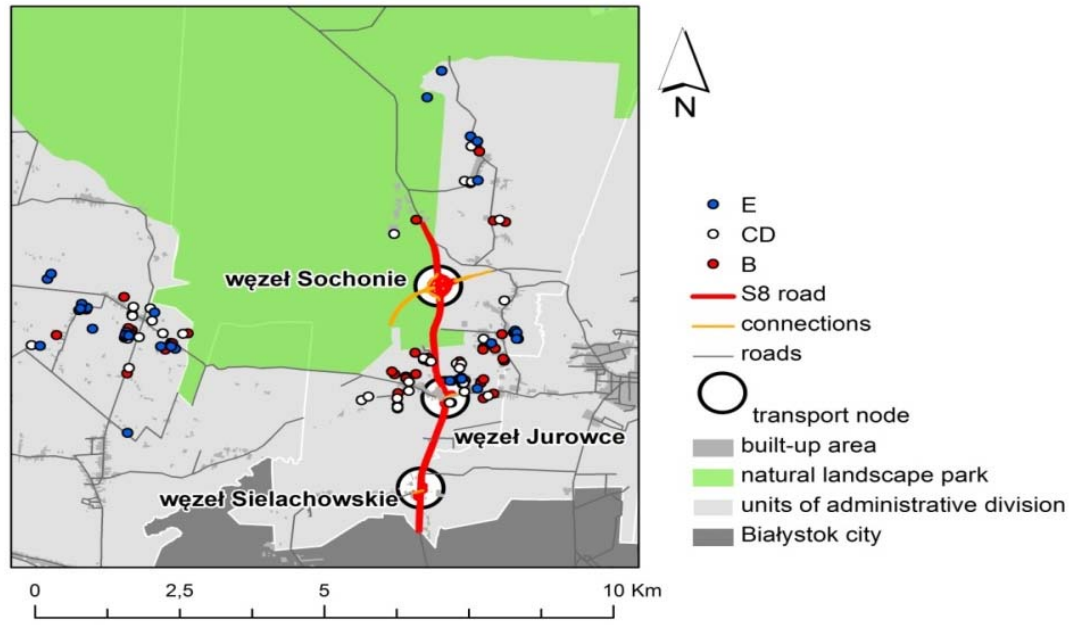

Fig. 5. Distribution of transactions analysed in the years 2003-2012 in three periods (B, CD, and E) of the execution of national road No. 8 along section Białystok-Sochonie-Katrynka. Source: own elaboration.

The analysis of the local property market at national road No. 8 along section Białystok-SochonieKatrynka was based on data from the register of property prices and values run for communes Wasilków and Dobrzyniewo Duże. Information on transactions concluded in the years 2003-2012 was used. The transactions analysed concerning undeveloped land are located along the route and in the vicinity of the villages of Letniki, Bohdan, and Podleńce, located in commune Dobrzyniewo Duże, at a distance from Białystok similar to that of the other communication junction "Sochonie", but not situated directly at national road No. 8 .

Analogically to the procedure presented in point 2.2 of the article, the transactions analysed were divided into three periods (Fig. 5):

1) 52 property sale transactions concluded in period $B$, 
2) 35 property sale transactions concluded in period CD,

3) 37 property sale transactions concluded in period $\mathrm{E}$.

Due to the small sample of transactions concluded in period A, they were not subject to analysis.

For the purpose of assessment of the similarity of prices of neighbouring transactions, the analysis of clusters of similar and varying values was conducted. The analysis results are presented in Figure 6.
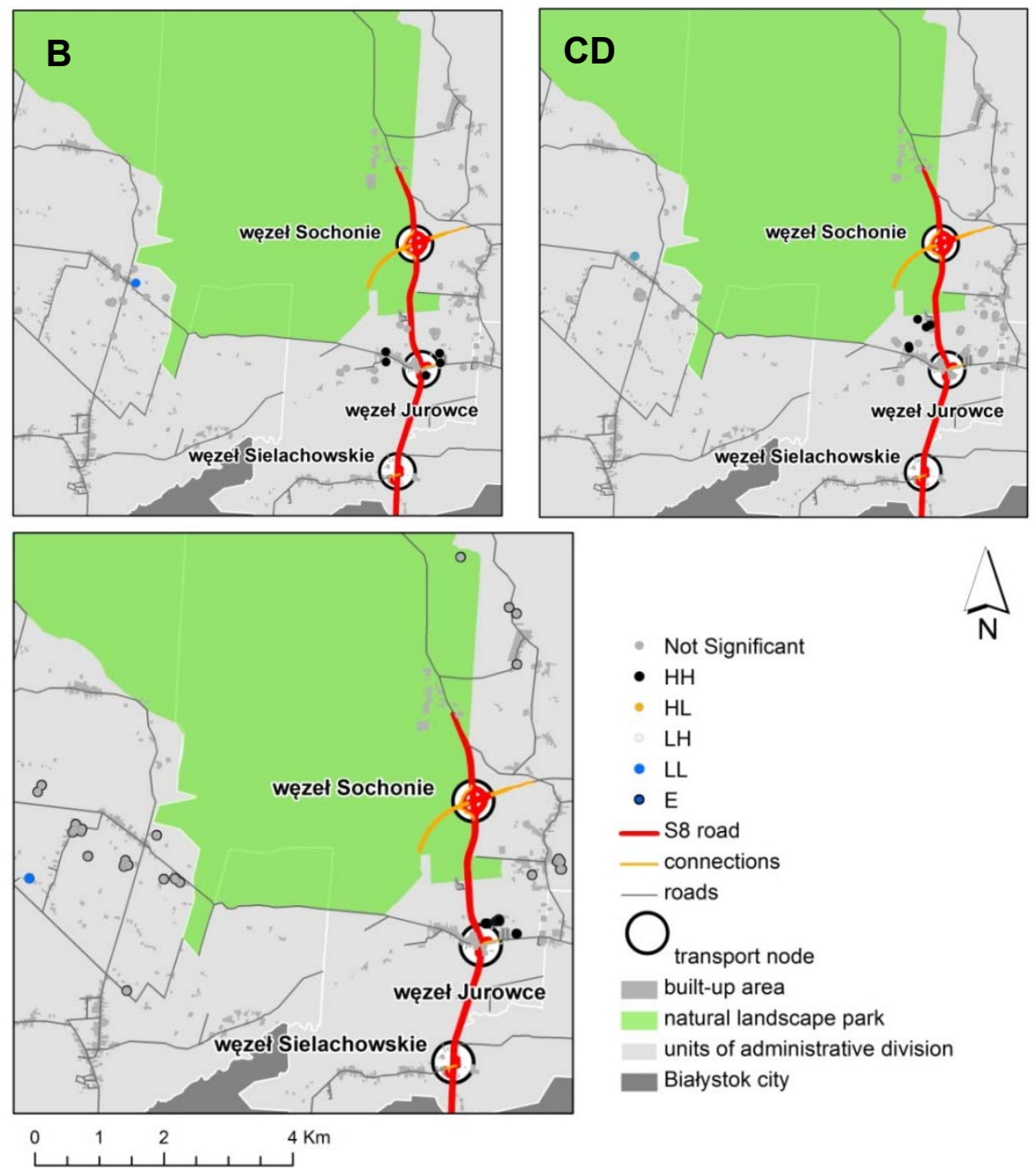

- Not Significant

- $\mathrm{HH}$

- $\mathrm{HL}$

LH

- LL

- $\mathrm{E}$

S8 road

connections

roads

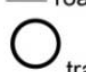

transport node

built-up area

natural landscape park

units of administrative division

Białystok city

Fig. 6. Results of the analysis of clusters of similar and varying values of properties in three periods: B, $\mathrm{CD}$, and E. Source: own elaboration.

In the period preceding the commencement of works on the extension of the road (B), clusters of high property values at the level of PLN 42-87/ $\mathrm{m}^{2}$ are recorded, located in Jurowce on the western and eastern side of the route. A cluster of low values is also visible, composed of one transaction from 2003 in Letniki, where a considerably higher number of transactions regarding parcels with irregular shape were recorded than those with investment possibilities.

In the period after the commencement of the extension of national road No. 8 (CD), a cluster of high values appears north of Jurowce. Those are transactions related to properties purposed for family residential housing from the period 2007-2008 with prices exceeding PLN $150 / \mathrm{m}^{2}$. In addition to the attractive location of the properties, the high prices were determined by among others the current situation on regional and national markets, i.e. the "investment boom" on the property market. A cluster of low values occurs again in the Letniki village. Due to the location at a large distance from national road No. 8, the property values do not increase.

After the completion of the extension, and commissioning of the road (period E), the situation on the property market in Jurowce and Letniki did not change, and the prices are at a level similar to those in periods $B$ and $C D$ of the investment implementation.

The analysis presented in Figure 6 suggests that for each of the periods of the investment implementation analysed, transactions with the highest prices were concluded in Jurowce. This results 
from the location of the village in the suburbs of Białystok, where strong urbanisation and increased demand for land is observed, resulting in different behaviour of market participants in relation to the rural property market. Jurowce is distinguished among other neighbouring rural areas in that it is subject to strong processes of spatial transformation due to the co-occurrence of elements typical of urban and rural areas. The extension of the road strengthened the tendency. For the purpose of further assessment whether the tendency is decreasing or increasing, the hot spot analysis was conducted. A Getis-Ord $\mathrm{Gi}^{*}$ statistic measure was determined for each transaction, calculated as the ratio of the sum of values of neighbouring transactions to the sum of all values, and the " $z$ " measure, permitting the assessment of the statistical significance of the results obtained. The local sum for a feature and its neighbors is compared proportionally to the sum of all features. When the local sum largely differs from the expected local sum, and the difference is too large to be the result of random chance, a statistically significant " $\mathrm{z}$ " value is the result. For statistically significant positive " $\mathrm{z}$ " value, the larger the " $z$ " value, the more intense the clustering of high values (hot spot). For statistically significant negative $z$-value, the smaller the $z$-value, the more intense the clustering of low values (cold spot) (ArcGIS 10.1. Help). The assessment of the " $z$ " value permits the determination of the intensity of the occurring clusters. Figure 7 suggests that the cluster of high transaction prices is located closer and closer to the junction, but its intensity decreases.
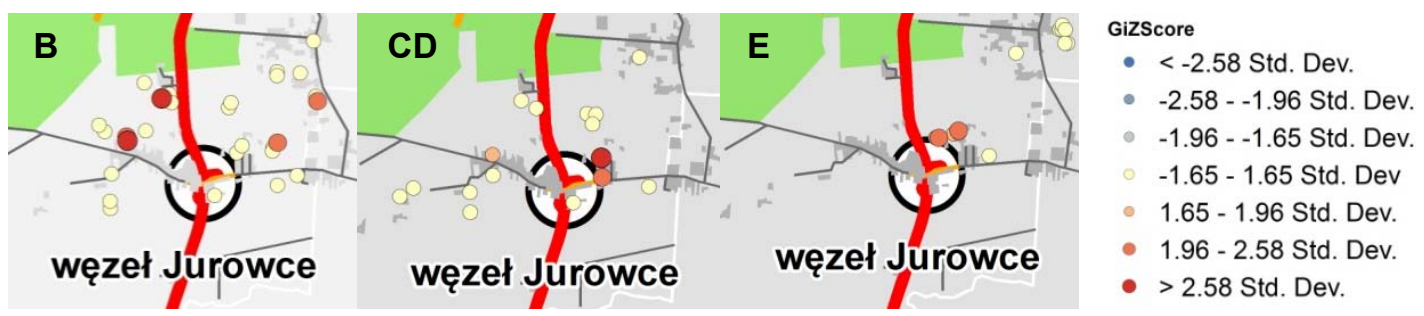

Fig. 7. Results of the hot spot analysis - vicinity of the "Jurowce" junction. Source: own elaboration.

\subsubsection{Classification of properties by transaction date and unit price}

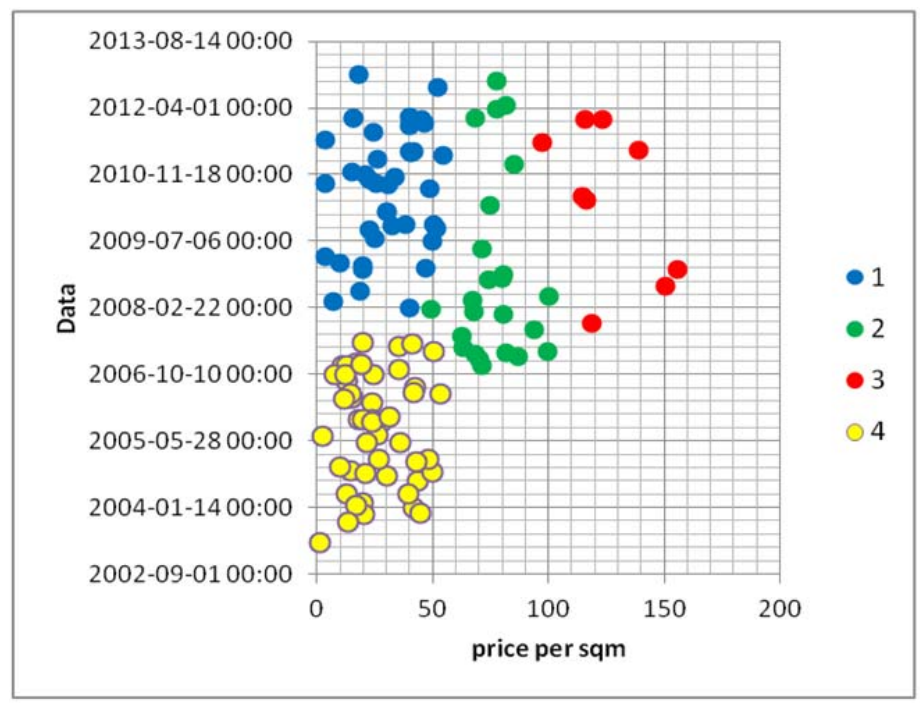

Fig. 8. Classification of transactions by the criteria of transaction date and price per $1 \mathrm{~m}^{2}$. Source: own elaboration.

Properties were classified by transaction date and unit price, and consequently divided into four groups (Fig. 8):

- group 1, marked with blue colour, represents transactions concluded after the commencement of the construction of the road, and distinguished by low prices;

- group 2, marked with green colour, represents transactions concluded after the commencement of the construction of the road, and distinguished by average prices;

- group 3, marked with red colour, represents transactions concluded after the commencement of the construction of the road, and distinguished by high prices; 
- group 4, marked with yellow colour, represents transactions concluded before the commencement of the construction of the road, and distinguished by low prices.

Figure 8 shows that transactions with high prices were concluded from October 2006 and from mid 2007. It is a period just before the commencement of the construction, at the time of approving of the location decision.

The spatial distribution of transactions belonging to particular groups is presented in Figure 9 .
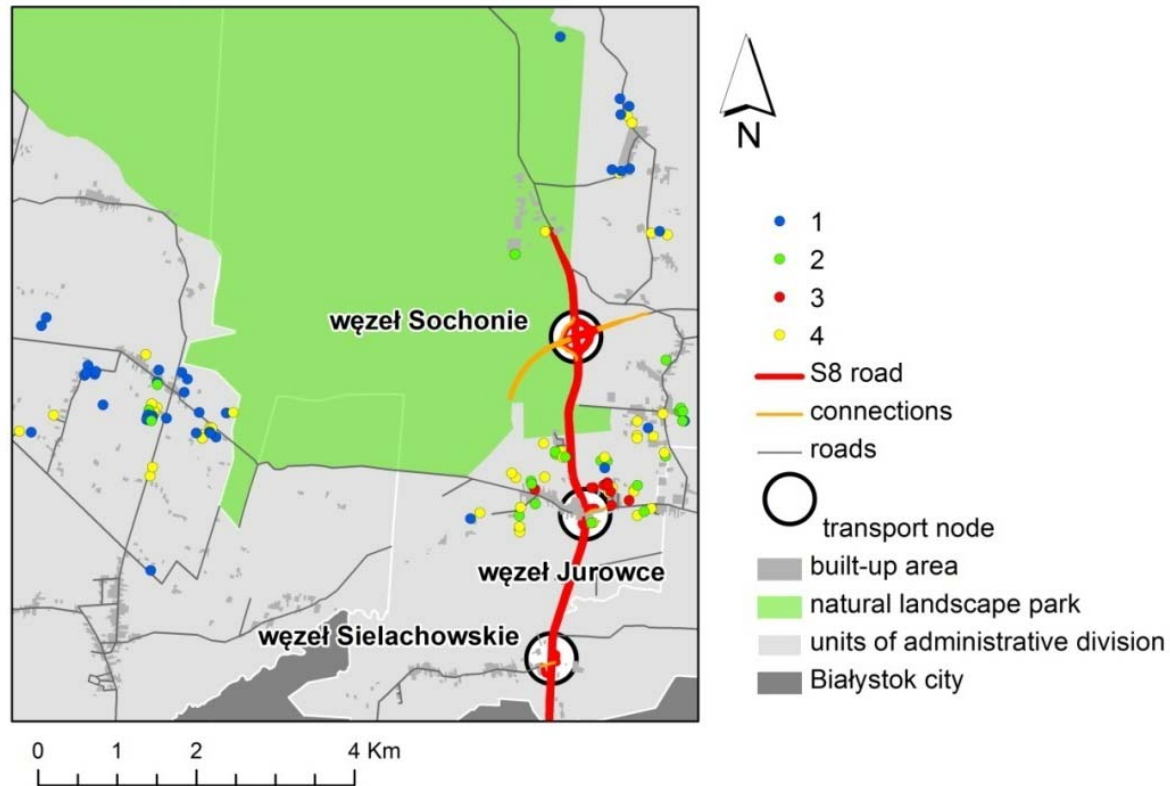

Fig. 9. Distribution of transactions belonging to particular groups. Source: own elaboration.

Low transaction prices from before the commencement of the construction of the section of national road No. 8 (marked with yellow colour) occur in the entire area analysed. After the commencement of the construction, the number of transactions with high prices (marked with red colour) increases, with an accumulation around the "Jurowce" junction. Many transactions with average prices (marked with green colour) also occur there, as well as a low number of transactions with low prices (marked with blue colour). The extension of the road along section BiałystokSochonie-Katrynka also resulted in the vevival of the land market in villages along the route. Those villages include: Wólka Przedmieście and Sochonie, and villages in its vicinity, i.e. Letniki, Bohdan, and Podleńce. The transaction prices per square meter obtained on the markets, however, are twice lower than the prices obtained in Jurowce, provided with good communication with national road No. 8.

\section{Summary and conclusions}

The study involving the analysis of the effect of national roads on the development and dynamics of changes in prices of land in their vicinity, with the application of the Geographic Information Systems technology, suggests the following conclusions:

1) Transaction data should be stored in the form of a database permitting their simple reference to referential spatial data, i.e. cadastre data. Such a solution permits and facilitates conducting spatial analyses.

2) Geographic Information Systems permit integration of data with referential data, and the existing software, among others ArcGIS ESRI, used for the purposes of the study, has implemented functions of statistical spatial analysis which can be used for:

- detection of clusters occurring in the vicinity of high or low values, and detection of varying values (the Anselin's method of local value of Moran's coefficient I). The analysis of clusters in various periods of time permits the assessment of the dynamics of changes in transaction prices.

- classification into natural groups of transactions according to the criteria of date and price per square meter, permitting the determination of the moment of appearance of a group of higher values. 
3) The analysis in areas located along the Mińsk Mazowiecki ring road and national road No. 8 section Białystok-Sochonie-Katrynka revealed that the market of land properties with investment possibilities revives at the moment of commencement of construction works, and when the works are close to completion with visible final effect. The process intensifies along the decreasing distance from urban centres located on route.

4) The road investment contributes to the strengthening of the differentiation of transaction prices. Areas considered attractive before, located close to urban areas, were distinguished by even higher prices after the commencement of the road construction. Areas located farther from the urban centre started generating clusters of relatively low values in spite of the vicinity of road junctions.

5) The construction of both roads was completed a short time ago, and few transactions have been observed. Is the residential function of rural areas close to road junctions bound to develop intensively? This question can only be answered in several years.

\section{Literature}

ArcGIS 10.1 Help Library.

CAlinSKi R. B., HARABASZ J., 1974, A Dendrite Method for Cluster Analysis, Communications in Statistics 3: $1-27$.

GoodChILD M. F., 1986, Spatial Autocorrelation. CATMOG 47, Geo Books.

Mitchell A., 2005, Spatial Measurements \& Statistics. In: The Esri Guide to Gis Analysis, vol 2, Esri Press.

Pang-Ning T., SteInbaCh M., KumaR V.,2006,Cluster Analysis: Basic Concepts and Algorithms. In: Introduction to Data Mining, Addison-Wesley Companion Book Site.

RADZISZEWSKA W., JAROSZEWICZ J., SZAFRANEK A., 2012,Rozkład przestrzenny wartości rynkowych gruntów przeznaczonych pod zabudowe mieszkaniowa na obszarach wiejskich $w$ sferze oddziaływania miasta, s. 105127. W:Planowanie rozwoju przestrzeni wiejskiej, KUROWSKA K., GWIAŹDZIŃSKA-GORAJ M. (red.), Studia Obszarów Wiejskich, tom XXIX,Warszawa.

WOLNY A.,ŹRÓBEKR., 2008, Wpływ decyzji administracyjnych zatwierdzających projekt podziału nieruchomości na rozwój obszarów wiejskich, Acta Scientiarum Polonorum, seria Administratio Locorum, $\mathrm{nr}$ 7(2): 57-68.

The regulation of the Minister of Transport and Marine Economy of 2 March 1999 on technical conditions required for public roads and their location (Dz. U. Nr 43, poz. $430 \mathrm{z}$ późn. zm.).

Environmental impact report.Materials for the application about decision on environmental conditions. Construction project - ring road of Mińsk Mazowiecki (with motorway parameters) along national road No. 2 section Choszczówka-Węzeł Ryczołek, Warsaw 2006.

www.a2obwodnica-minska.pl 11.02.2013. 